\title{
Ionizing Radiation Exposure and the Development of Soft-Tissue Sarcomas in Atomic-Bomb Survivors
}

\author{
Dino Samartzis, DSc, MSc, Nobuo Nishi, MD, PhD, John Cologne, PhD, Sachiyo Funamoto, BS, Mikiko Hayashi, BA, \\ Kazunori Kodama, MD, PhD, Edward F. Miles, MD, Akihiko Suyama, MD, PhD, Midori Soda, MD, and Fumiyoshi Kasagi, PhD \\ Investigation performed at the Radiation Effects Research Foundation, Hiroshima and Nagasaki, Japan
}

\begin{abstract}
Background: Very high levels of ionizing radiation exposure have been associated with the development of soft-tissue sarcoma. The effects of lower levels of ionizing radiation on sarcoma development are unknown. This study addressed the role of low to moderately high levels of ionizing radiation exposure in the development of soft-tissue sarcoma.
\end{abstract}

Methods: Based on the Life Span Study cohort of Japanese atomic-bomb survivors, 80,180 individuals were prospectively assessed for the development of primary soft-tissue sarcoma. Colon dose in gray (Gy), the excess relative risk, and the excess absolute rate per Gy absorbed ionizing radiation dose were assessed. Subject demographic, age-specific, and survival parameters were evaluated.

Results: One hundred and four soft-tissue sarcomas were identified (mean colon dose $=0.18$ Gy), associated with a $39 \%$ five-year survival rate. Mean ages at the time of the bombings and sarcoma diagnosis were 26.8 and 63.6 years, respectively. A linear dose-response model with an excess relative risk of 1.01 per Gy ( $95 \%$ confidence interval [Cl]: 0.13 to $2.46 ; p=0.019)$ and an excess absolute risk per Gy of 4.3 per 100,000 persons per year (95\% Cl: 1.1 to $8.9 ; p=$ 0.001 ) were noted in the development of soft-tissue sarcoma.

Conclusions: This is one of the largest and longest studies (fifty-six years from the time of exposure to the time of followup) to assess ionizing radiation effects on the development of soft-tissue sarcoma. This is the first study to suggest that lower levels of ionizing radiation may be associated with the development of soft-tissue sarcoma, with exposure of 1 Gy doubling the risk of soft-tissue sarcoma development (linear dose-response). The five-year survival rate of patients with soft-tissue sarcoma in this population was much lower than that reported elsewhere.

Level of Evidence: Prognostic Level I. See Instructions for Authors for a complete description of levels of evidence.

$\mathrm{S}$ oft-tissue sarcomas are malignant connective tissue lesions of mesenchymal origin that can manifest at any location throughout the body, are challenging to treat, and generally have been associated with poor prognostic outcomes $^{1-3}$. Soft-tissue sarcomas represent approximately $0.6 \%$ of all cancer cases ${ }^{4}$. Various etiological risk factors, such as environmental exposures to various chemicals ${ }^{5,6}$, viruses ${ }^{7}$, exogenous hormonal influences ${ }^{8}$, increased body-mass index ${ }^{9}$, genetic determinants ${ }^{10,11}$, and high levels of ionizing radiation ${ }^{12-23}$, have been associated with the development of soft-tissue sarcoma.

Radiation-induced soft-tissue sarcomas may occur as secondary cancers attributed to radiation therapy ${ }^{12,14,15,24}$ or Thoro- trast (thorium dioxide) induction ${ }^{13}$, with radiation doses from 9 gray $(G y)$ or higher ${ }^{16-23}$ and variable latency periods ${ }^{25}$. In fact, worse prognostic outcomes have been associated with radiationinduced soft-tissue sarcomas ${ }^{26-28}$; however, the role of low to moderately high levels of ionizing radiation exposure on the development of soft-tissue sarcomas is unknown. Until recently, it was a long-held belief that bone sarcomas were induced by very high levels of ionizing radiation exposure (i.e., >10 Gy). However, due to a recent study by Samartzis et al..$^{29}$, which was based on atomic-bomb survivors, the authors concluded that much lower levels of radiation exposure than previously believed may lead to the development of bone sarcomas.

Disclosure: None of the authors received payments or services, either directly or indirectly (i.e., via his or her institution), from a third party in support of any aspect of this work. One or more of the authors, or his or her institution, has had a financial relationship, in the thirty-six months prior to submission of this work, with an entity in the biomedical arena that could be perceived to influence or have the potential to influence what is written in this work. No author has had any other relationships, or has engaged in any other activities, that could be perceived to influence or have the potential to influence what is written in this work. The complete Disclosures of Potential Conflicts of Interest submitted by authors are always provided with the online version of the article. 


\section{TABLE I Soft-Tissue Sarcoma Rates by Colon Dose in Units of Weighted Gray (Gy), with Relative Weight of 10 for Neutrons} Versus Gamma Radiation

\begin{tabular}{|c|c|c|c|}
\hline $\begin{array}{l}\text { Colon Dose (Gy) of Atomic-Bomb } \\
\text { Survivors (person-year } \\
\text { weighted mean) }\end{array}$ & Person-Years & $\begin{array}{c}\text { Observed Soft-Tissue } \\
\text { Sarcoma Cases (expected) }\end{array}$ & $\begin{array}{c}\text { Rate of Sarcomas per } \\
\text { 100,000 Person-Years } \\
\text { (age, birth-year } \\
\text { adjusted) }[95 \% \mathrm{Cl}]\end{array}$ \\
\hline$<0.005 *(0.0007)$ & 956,946 & $39(41.6)$ & $4.4[3.1$ to 5.9$]$ \\
\hline 0.005 to $0.1(0.030)$ & 760,551 & $36(32.7)$ & $5.1[3.6$ to 7.0$]$ \\
\hline 0.1 to $0.2(0.14)$ & 152,461 & $9(6.7)$ & $6.2[3.0$ to 11$]$ \\
\hline 0.5 to $1(0.70)$ & 84,383 & $9(3.7)$ & $11.4[5.5$ to 21$]$ \\
\hline 1 to $2(1.3)$ & 42,829 & $4(1.8)$ & 10.4 [3.2 to 24$]$ \\
\hline $2+(2.4)$ & 14,136 & $1(0.5)$ & 8.6 [0.5 to 38$]$ \\
\hline
\end{tabular}

* Subjects with radiation dose $<0.005$ served as control subjects being exposed to either no or very minimal amounts of radiation equivalent to annual background radiation doses, which facilitated comparisons to subjects with exposure to higher doses.

Due to the increase of ionizing radiation exposure in medical and occupational settings as well as a potential risk that may stem from nuclear facility catastrophes (e.g., Chernobyl, Three Mile Island, and Fukushima Daiichi) ${ }^{30-35}$, as well as those associated with radiation therapy in general and newer, more conformal techniques that tend to increase the amount of normal tissue exposed to low to moderate doses of ionizing radiation, there is a need to understand if these sources of exposure may lead to the development of soft-tissue sarcoma. Therefore, a prospective, longitudinal study was performed to assess the role of low to moderately high levels (i.e., 0 to approximately $3 \mathrm{~Gy}$ ) of ionizing radiation exposure on the development of soft-tissue sarcomas in the context of the Life Span Study (LSS) cohort of Japanese atomic-bomb survivors of Hiroshima and Nagasaki.

\section{Materials and Methods}

\section{Study Design and Population}

prospective, longitudinal study was performed of atomic-bomb survivors A (time of exposure: August, 1945) from Hiroshima and Nagasaki, Japan, who were part of the LSS cohort $(\mathrm{N}=120,321)$ of the Radiation Effects Research Foundation (RERF) to assess the development of soft-tissue sarcoma. Characteristics of the LSS cohort have been previously reported ${ }^{29,36-42}$. The last update of the LSS was in 2001. This was the case because gathering of data and materials in a systematic and meticulous manner in the prefectures of Hiroshima and Nagasaki took several years to complete. Some information necessitated special arrangement with local medical institutions. Since the tumor registries of Hiroshima and Nagasaki were established on January 1, 1957, and January 1, 1958, respectively, any individuals who were deceased, diagnosed with cancer, or lost to follow-up before January of 1958 were excluded from the study (Fig. 1). Furthermore, individuals with unknown doses or residencies outside the cities at the time of the bombings were also excluded from the study (Fig. 1). Colon doses were used as a good approximation to dose for all soft tissue, and were estimated in units of weighted Gy according to the Dosimetry System of 2002 (DSO2), making allowance for biological effectiveness in that neutrons were weighted 10 and gamma $1^{43}$. Since disease mechanisms may entail systemic effects following whole-body radiation exposure, colon dose has been used to approximate whole-body doses in the LSS cohort, which also facilitates comparisons between disease ${ }^{39}$.

\section{Identification and Clinical Assessment of Sarcomas}

Utilizing the Hiroshima and Nagasaki Tumor Registries, primary and malignant soft-tissue sarcomas were identified and further verified on the basis of autopsy reports, death certificate records, and tissue registry information ${ }^{44}$. Diagnosis of soft-tissue sarcoma development was based on initial physician consultation and treatment regarding tumor-related symptoms or diagnosis irrespective of symptoms further verified pathologically. If the tumor was discovered during an autopsy, it was considered as being pathologically diagnosed. Tumors diagnosed outside of the tumor registry catchment area were excluded. The site of origin and histological characteristics of the tumors were identified based on the World Health Organization's International Classification of Diseases for Oncology (ICD-O), 1st to 3rd editions. Age at the time of the bombings, age at sarcoma diagnosis (attained

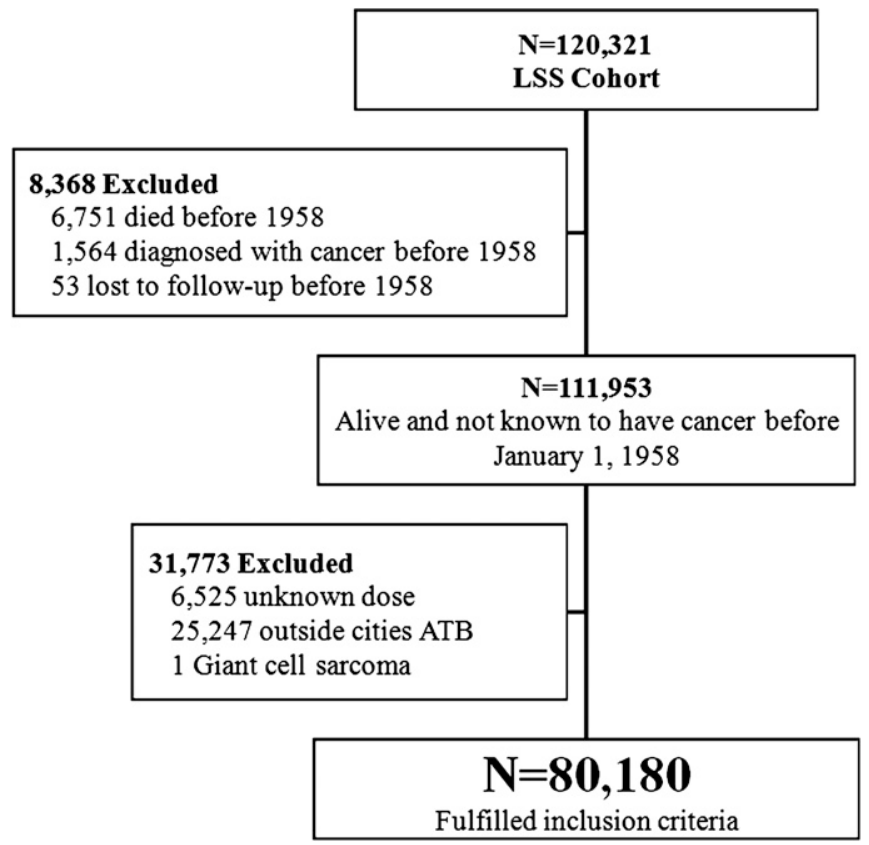

Fig. 1

Flow diagram of study population exclusions and inclusions. ATB $=$ at time of bombings. 
The Journal of Bone \& Joint Surgery $\cdot$ Jbjs.org Volume 95-A · Number 3 - February 6, 2013
Ionizing Radiation Exposure and the Development of Soft-Tissue Sarcomas in Atomic-Bomb Survivors age), duration from exposure to sarcoma development, development of metastases, and five-year survival rate were assessed.

\section{Statistical Analysis}

Descriptive and frequency analysis was calculated of various subject and radiation parameters as well as for site of origin and histological types of soft-tissue sarcomas. Rates were computed based on Poisson regression modeling of grouped survival $\operatorname{data}^{45}$. Person-years of observation were accumulated from January 1, 1958, to the event of first tumor diagnosis, death, or December 31, 2001, whichever came first. After implementing appropriate background functions in age and year of birth, various dose-response associations were assessed to determine the best-fitting model (i.e., linear, linear quadratic, quadratic, spline, and threshold) and to assess radiation effects on two scales: the multiplicative excess relative risk (ERR: total rate $=[$ background rate $] \times[1+$ ERR $])$ and the additive excess absolute rate $($ EAR: total rate $=$ background rate + EAR). The ERR, which is the standard model used in radiation epidemiology, allows for analysis of the excess radiation-related incidence separately from background incidence. Models were fitted with use of Epicure statistical software (Seattle, Washington ${ }^{45}$. Effect modification by sex, age at exposure, or age at sarcoma diagnosis was assessed with likelihood ratio tests that made use of log-linear effect-modifier models on each scale. Dose-response models and the ERR-EAR scales were compared with use of the Akaike information criterion (AIC) (the deviance plus twice the number of parameters, including the joint point in the case of the spline model or the threshold in the case of the threshold model $)^{46,47}$. The best-fitting model was selected on the basis of the lowest value of the AIC. Kaplan-Meier analysis was performed to determine the five-year survival rate. Mann-Whitney $U$ tests were performed to assess two independent samples. All $\mathrm{p}$ values were two-sided and significance was declared at $\mathrm{p}<0.05$, considering the $95 \%$ confidence interval (CI) bounds for precision.

\section{Ethics Approval}

The conduct of the LSS was approved by the Human Investigation Committee of the RERF. The use of death certificates of the LSS subjects was approved by the Japanese Ministry of Internal Affairs and Communications. The respective committees of the Hiroshima City Cancer Registry, Hiroshima Prefecture Tissue Registry, and Nagasaki Prefecture Cancer Registry approved the use of cancer registry data for the present study.

\section{Sources of Funding}

The Radiation Effects Research Foundation of Hiroshima and Nagasaki, Japan, is a private, nonprofit foundation funded by the Japanese Ministry of Health, Labour and Welfare and the United States Department of Energy, the latter in part through the United States National Academy of Sciences. However, no author received any funds that have a financial or personal conflict of interest in relation to the current study.

\section{Results}

7 here were 80,180 individuals who met the inclusion criteria, with a total of $2,170,732$ person-years (37\% males, $63 \%$ females) of observation (Table I). Of those individuals, 104 softtissue sarcoma cases were identified, which consisted of thirty-six males (34.6\%) and sixty-eight females (65.4\%). The overall crude incidence associated with soft-tissue sarcomas was 4.8 per 100,000 person-years (4.4 in males, 5.0 in females). The crude baseline $(<0.005$ Gy exposure) incidence (observed cases/person-years) was 4.1 per 100,000 person-years, similar to the age-and-birth-year-adjusted incidence of 4.4 per 100,000 person-years in that group (Table I). Twenty-seven cases were confirmed on autopsy and two were confirmed by death certificate. No difference in radiation dose was noted between those cases confirmed on autopsy or death (mean:
$0.24 \mathrm{~Gy} ; \pm$ standard deviation [SD]: $0.53 \mathrm{~Gy}$; range: 0 to 2.35 Gy) compared with those diagnosed alternately (mean: 0.16 Gy; \pm SD: 0.35 Gy; range: 0 to $1.82 \mathrm{~Gy})(\mathrm{p}=0.279)$.

Among the soft-tissue sarcoma cases, the mean age at the time of the bombings was 26.8 years ( \pm SD: 15.9 years; range: zero to seventy years) and the mean age at diagnosis was 63.6 years ( \pm SD: 14.0 years; range: twenty-six to ninety-three years). The time period from exposure to diagnosis (potential latency period) of the sarcoma was 36.8 years ( \pm SD: 12.5 years, range: fourteen to fifty-six years). The mean colon dose was 0.18 Gy ( \pm SD: $0.40 \mathrm{~Gy}$, range: 0 to $2.35 \mathrm{~Gy}$ ).

The majority of cases occurred in the uterus $(n=17$, $16.3 \%)$ and stomach $(\mathrm{n}=14,13.5 \%)$ (Table II). According to histology, the majority of sarcomas were leiomyosarcomas $(\mathrm{n}=37,35.6 \%)$ and malignant fibrous histiocytomas $(\mathrm{n}=11$, $10.6 \%$ ) (Table III). Due to varied site of origin and histology, the authors could not discern with confidence the effects of colon-dose radiation exposure and the development of specific sarcoma types.

\section{TABLE II Site of Origin of Soft-Tissue Sarcomas in Atomic-Bomb Survivors

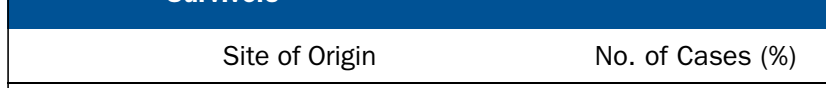

Connective, subcutaneous, and

$28(26.9)$

soft tissues

Extremities $(n=10)$

Head/face/neck $(n=6)$

Thorax $(n=2)$

Pelvis $(n=4)$

Abdomen $(\mathrm{n}=1)$

Trunk, NOS* $(n=5)$

Uterus

17 (16.3)

Stomach

Cavities of the trunk (mediastinum,

peritoneum, and retroperitoneum)

Head glands (parotid, submandibular, and lacrimal)

Intestines

Skin

Heart

Neural (cerebral, peripheral)

Breast

Head cavities (oral and nasal)

2 (1.9)

Bladder

$1(1.0)$

Esophagus

$1(1.0)$

Kidneys

$1(1.0)$

Liver

$1(1.0)$

Total

$104(100 \%)$

*NOS $=$ not otherwise specified. 
The Journal of Bone \& Joint Surgery · Jbjs.org Volume 95-A • Number $3 \cdot$ February 6, 2013

\begin{tabular}{|lc|}
\hline \multicolumn{1}{|c|}{ TABLE III Histology of Soft-Tissue Sarcomas in Atomic-Bomb } \\
\hline \multicolumn{1}{|c|}{ Hurvivors } & No. of Cases (\%) \\
\hline Leiomyosarcoma & $37(35.6)$ \\
Malignant fibrous histiocytoma & $11(10.6)$ \\
Malignant mixed tumor & $8(7.7)$ \\
Malignant peripheral nerve sheath tumor & $7(6.7)$ \\
Hemangiosarcoma & $6(5.8)$ \\
Fibrosarcoma & $6(5.8)$ \\
Endometrial stromal & $4(3.8)$ \\
Soft-tissue sarcoma, NoS* & $4(3.8)$ \\
Liposarcoma & $3(2.9)$ \\
Carcinosarcoma & $2(1.9)$ \\
Malignant cystosarcoma phyllodes & $2(1.9)$ \\
Dermatofibrosarcoma & $2(1.9)$ \\
Müllerian mixed tumor & $2(1.9)$ \\
Myxofibrosarcoma & $1(1.0)$ \\
Malignant granular-cell tumor & $1(1.0)$ \\
Malignant hemangioendothelioma & $1(1.0)$ \\
Malignant hemangiopericytoma & $1(1.0)$ \\
Malignant meningioma & $1(1.0)$ \\
Myxoid liposarcoma & $1(1.0)$ \\
Pleomorphic liposarcoma & $1(1.0)$ \\
Rhabdomyosarcoma & $1(1.0)$ \\
Small cell sarcoma & $1(1.0)$ \\
Synovial sarcoma & $1(1.0)$ \\
Total & \\
\hline & \\
\hline & \\
\hline
\end{tabular}

Adjusting for age at diagnosis and year of birth, incidence was higher among exposed persons than among persons with $<0.005$ Gy exposure, evidencing a trend despite the small numbers of cases and with persons exposed to $>0.5$ Gy showing observed numbers of cases about double the number expected if there were no radiation effect (Table I). ERR model comparisons of radiation effect on soft-tissue sarcoma development revealed that a linear dose-response model fit better $(\mathrm{AIC}=$ 968.15) than linear-quadratic (AIC $=970.09)$, quadratic $(\mathrm{AIC}=$ 969.43), spline $(\mathrm{AIC}=971.85)$, or threshold $(\mathrm{AIC}=969.93)$ models. The linear ERR, 1.01 per Gy (95\% CI: 0.13 to $2.46, \mathrm{p}=$ 0.019), was significant (Fig. 2). In addition, the risk of sarcoma development significantly increased with increasing year of birth $(\mathrm{p}=0.037)$ and with increasing age at diagnosis $(\mathrm{p}<$ $0.001)$; however, sex was not a strong predictive factor $(\mathrm{p}>$ $0.5)$. With the EAR model, the estimated excess rate per Gy was 4.32 per 100,000 persons per year (95\% CI: 1.14 to 8.94 , $\mathrm{p}=0.001)$. The ERR and EAR remained significant after excluding persons exposed to 2 Gy or more (ERR 1.23, 95\% CI: 0.18 to $2.94, \mathrm{p}=0.015$; EAR 4.92, 95\% CI: 1.06 to $10.40, \mathrm{p}=0.006)$.
Ionizing Radiation Exposure and the Development of Soft-Tissue Sarcomas in ATomic-Bomb Survivors
The ERR model demonstrated significant radiation effect modification by age of diagnosis (log-linear effect modifier parameter $-3.7,95 \% \mathrm{CI}:-6.4$ to $-0.8, \mathrm{p}=0.017$, AIC $=$ 962.40), but not the EAR model ( $\mathrm{p}>0.5$; for unmodified EAR, AIC $=961.49)$. Neither sex nor age at exposure significantly modified the ERR marginally $(\mathrm{p}=0.38$ and $\mathrm{p}=$ 0.065 , respectively) or after accounting for modification by age of diagnosis ( $\mathrm{p}>0.5$ and $\mathrm{p}=0.43$, respectively), nor did either factor modify the attained-age-constant EAR ( $p>0.5$ and $\mathrm{p}=0.21$, respectively). The log-linear parameter for log age in the unmodified EAR model was 3.4 (95\% CI: 2.30 to 4.70$)$, consistent with the attained age modifier of the $\operatorname{ERR}(-3.7)$.

Based on the last LSS assessment of soft-tissue sarcoma cases, twenty-three individuals were alive (22.1\%). Metastases had occurred in forty-six individuals $(44.2 \%)$ by the time of the last follow-up. The mean survival period after diagnosis was 7.1 years ( \pm SD: 9.1 years; range: zero to fortyfour years). The five-year survival rate was $39 \%$, which did not statistically differ between sex, age at diagnosis, and sarcoma site of origin or histology $(p>0.05)$. Regression analysis did not note such factors to be significantly predictive in this population. However, individuals in whom metastases developed had a significantly shorter survival period (mean: 3.0 ; $\pm \mathrm{SD}$ : 4.0 ; range: zero to twenty-one years) than did those without metastases (mean: 9.5; \pm SD: 8.7; range: zero to thirty-one years) at the time of the last assessment $(\mathrm{p}<0.001)$. The five-year survival rate for individuals in whom metastases developed as compared with those with no metastases was $17.4 \%$ and $53.4 \%$, respectively (Fig. 3 ). The effects of treatment type on survival rate could not be discerned from this study.

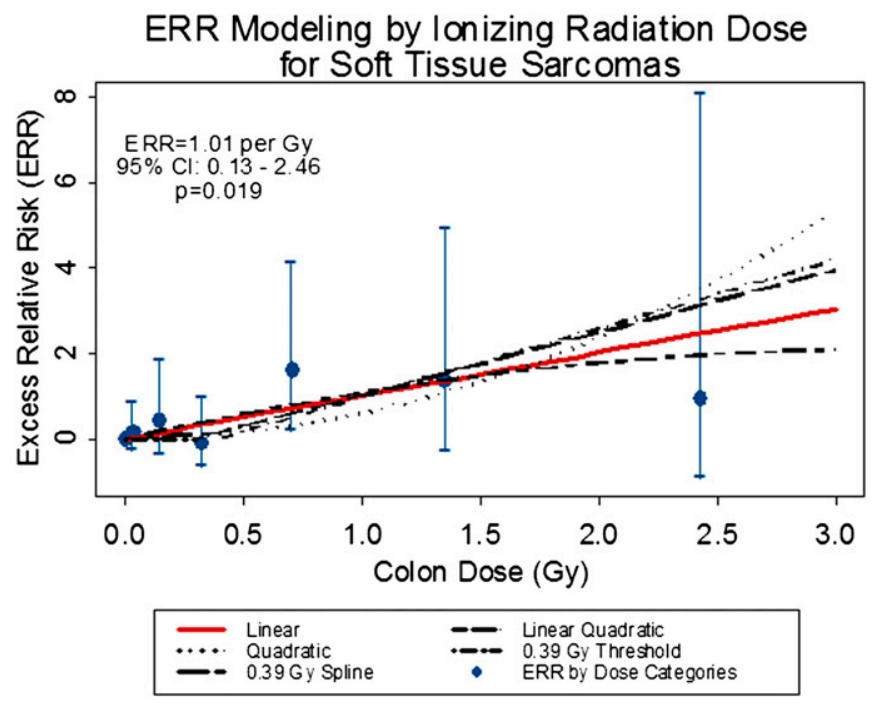

Fig. 2

Illustration of various excess relative risk (ERR) dose-response models for colon dose in units of weighted gray (Gy), with a relative weight of 10 for neutrons compared with gamma radiation. Baseline models were adjusted for age at the time of sarcoma diagnosis and year of birth. 


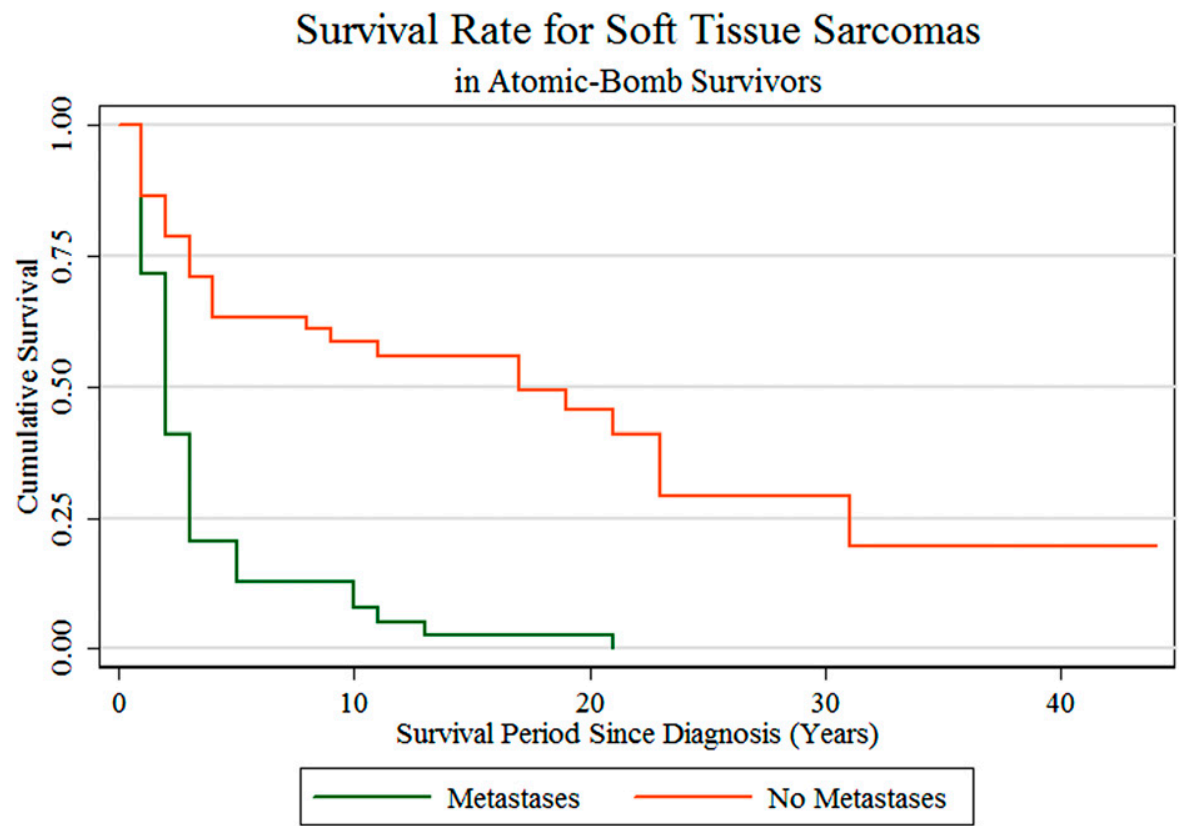

Fig. 3

Nonadjusted survival analysis of patients with soft-tissue sarcomas stratified by the presence of metastases. The overall five-year survival rate was $39 \%$. Five-year survival rates with or without metastases were $17.4 \%$ and $53.4 \%$, respectively.

\section{Discussion}

Cxposure to ionizing radiation can lead to tissue damage Cand genetic mutation, resulting in numerous cancerous or noncancerous diseases ${ }^{48,49}$. Ionizing radiation exposure has been of paramount public-health concern, further brought to light due to the recent breakdown of the Fukushima Daiichi nuclear power plant in Japan in March of 2011. Although radiation therapy is often utilized to treat cancerous lesions, studies have shown that the use of ionizing radiation modalities (e.g., radiographs, computed tomography scans, fluoroscopy) for diagnostic and as surgical adjuncts continues to rise and that these modalities on many occasions have been utilized quite liberally, increasing radiation exposure to the patient and at times to the health-care practitioner ${ }^{30-32,34,50}$. In fact, the use of ionizing radiation in the medical setting in the United States has increased fourfold from the early 1980s to $2006^{51}$.

The atomic-bomb survivors of Hiroshima and Nagasaki, Japan, are the world's largest and most unique source of information to assess the effects of low to moderately high levels of ionizing radiation on the development of cancer and noncancerous disease. This population was exposed to whole-body ionizing radiation at the time of the bombings in August of 1945 and has been systematically assessed since then for the development of disease as part of the LSS cohort $^{29,36-42}$. Approximately 25,000 subjects of this cohort served as "control subjects," having been exposed to either no or very minimal (i.e., $<0.005 \mathrm{~Gy}$ ) amounts of radiation equivalent to annual background radiation doses, which facilitated comparisons to subjects with exposure to higher doses (Fig. 2, Table I). As such, the LSS cohort of atomic-bomb survivors has broadened the understanding of the effects of ionizing radiation on the development of disease and has contributed to radiation protection guidelines and prevention initiatives.

According to an analysis by Preston et al. ${ }^{39}$, who reported the cancer incidence in atomic-bomb survivors of Hiroshima and Nagasaki in the LSS cohort, sarcomas as a group (bone sarcomas included) exhibited an ERR per Gy of 0.48 (90\% CI: 0.07 to 1.4 ), with an EAR of 0.39 per 10,000 per person-year Gy (90\% CI: 0.08 to 1.04) at age seventy years, after exposure at age thirty years, in a linear fashion. However, according to a recent report by Samartzis et al. ${ }^{29}$, bone and soft-tissue sarcomas possess different susceptibilities to ionizing radiation exposure. In fact, Samartzis et al. ${ }^{29}$ reported that bone sarcomas present with a linear dose-response model with a threshold at $0.85 \mathrm{~Gy}$ and an ERR per Gy of 7.5 (95\% CI: 1.34 to $1.85 \mathrm{~Gy}$ ) in excess of 0.85 Gy.

To our knowledge, our study represents one of the largest and longest prospective evaluations of primary softtissue sarcomas arising in individuals who were exposed to a single whole-body dose of ionizing radiation. Our analyses revealed that soft-tissue sarcomas may be associated with exposure to low to moderately high levels of ionizing radiation, showing a linear dose-response (nonthreshold) model with an ERR of 1.01 per Gy. This linear dose-response model is in line with most other cancers attributed to radiation induction in atomic-bomb survivors of Hiroshima and $\mathrm{Na}-$ gasaki $^{39}$. Furthermore, negative effect modification of the ERR by attained age and age at exposure is seen with solid cancers overall in the LSS population ${ }^{39}$, but age at exposure 
The Journal of Bone \& Joint Surgery · Jbjs.org Volume 95-A • Number 3 · February 6, 2013
Ionizing Radiation Exposure and the Development of Soft-Tissue Sarcomas in Atomic-Bomb Survivors was only marginally significant in the present analysis. That age at diagnosis was a significant modifier of the ERR-but not the EAR-suggests that the excess rate may be constant with respect to attained age.

The most common histological types of soft-tissue sarcoma noted in atomic-bomb survivors were leiomyosarcomas and malignant fibrous histiocytomas, which is also generally similar in other population $\mathrm{s}^{52}$. Although there are numerically more women with soft-tissue sarcomas in the study population, the sex distribution of the exposed population essentially matches the sex distribution of individuals with soft-tissue sarcomas in the cohort, indicating no apparent effect of sex on the incidence of sarcoma induction.

Prognostic outcomes of soft-tissue sarcomas are dependent on numerous factors, such as histology, grade, size, location, duration, age of the patient, presence of metastases, treatment modality, surgical margin status, and age. In our study, the survival period was less in those individuals who experienced metastases. Furthermore, the five-year survival rate of all sarcomas was 39\% (17.4\% in subjects with metastases), which is much lower than that reported in epidemiological studies in which ionizing radiation exposure was not a factor. A recent Surveillance, Epidemiology and End Results (SEER) assessment noted that the five-year survival rate of all soft-tissue sarcomas was approximately $71 \%^{52}$. However, studies have shown that radiation-induced sarcomas have worse prognostic outcomes, which may further explain the lower survival rate in our study population ${ }^{26-28}$. As such, our study further stresses the important clinical impact of radiationinduced soft-tissue sarcomas and the need to prevent their occurrence.

With newer modalities, including intensity-modulated radiation therapy (IMRT), there is some evidence to suggest that the integral dose over the tissue receiving some dose is increased and that a larger volume of tissue adjacent to the target tissue may receive an appreciable dose of radiation ${ }^{53-55}$. This effect can be attributed to the greater number of beams generally utilized to increase conformality in IMRT, resulting in a greater number of entry and exit points exposed to some dose of radiation therapy. There is also increased leakage from the gantry head and through the multileaf collimator due to the greater number of monitor units required to deliver the specified therapeutic dos $\mathrm{e}^{56}$. For example, treatment of deep-seated pelvic tumors with the use of higher-energy beams to increase dose at depth for dose escalation ${ }^{57}$ and superficial tissue sparing ${ }^{58,59}$ can also be accompanied by an increased exposure of adjacent normal tissue due to the production of secondary neutron ${ }^{60,61}$. In this setting, the benefit of an increased ability to sculpt the dose to the desired target tissues and avoid organs at risk in the pelvis (such as the bladder and rectum) with IMRT must be weighed against the potential for increased shortterm and long-term risk to the patient-specifically, the increased risk of induction of secondary malignant tumors, including sarcomas.
Although our study represents the largest and longest longitudinal population-based initiative to assess the association between ionizing radiation exposure and soft-tissue sarcomas, as with any study, there are limitations. Since the risk factors of soft-tissue sarcomas were not well understood at the initiation of the LSS, information such as genetic factors and occupational hazards has not been collected systematically for all subjects. However, due to the inclusion of virtually all radiation-exposed persons in the design of the LSS, such variables are unlikely to be confounded with radiation dose in the cohort, apart from their potential impact on survival in the interim between exposure and initiation of cancer follow-up. However, the authors did attempt to exclude certain sarcomas, such as Kaposi sarcoma (none noted since 1980s), that may have a strong association with viruses and giant-cell tumors that are benign or have a questionable malignant nature.

In conclusion, our study attempts to raise awareness that even moderate levels of ionizing radiation exposurefrom medical imaging, radiation therapy, and environmental exposure-can lead to the development of soft-tissue sarcomas.

Note: The Radiation Effects Research Foundation (RERF), Hiroshima and Nagasaki, Japan, is a private, non-profit foundation funded by the Japanese Ministry of Health, Labour and Welfare (MHLW) and the U.S. Department of Energy (DOE), the latter in part through DOE Award DEHSO000031 to the National Academy of Sciences. This publication was supported by RERF Research Protocols RP 1-75 and 18-61. The authors thank Dr. Roy E. Shore and Dr. Evan Douple of RERF as well as Dr. Charles Land, Dr. Kiyohiko Mabuchi, and Dr. Elaine Ron of the Radiation Epidemiology Branch of the National Cancer Institute, National Institutes of Health of the United States, for their help with the study. The views of the authors do not necessarily reflect those of the two governments.

Dino Samartzis, DSc, MSc

Department of Orthopaedics \& Traumatology,

University of Hong Kong, Professorial Block, 5th Floor,

102 Pokfulam Road, Pokfulam, Hong Kong SAR, China.

E-mail address: dsamartzis@msn.com; dspine@hku.hk

Nobuo Nishi, MD, $\mathrm{PhD}$

National Institute of Health and Nutrition,

1-23-1 Toyama, Shinjuku-ku,

162-8636 Tokyo, Japan

John Cologne, $\mathrm{PhD}$

Sachiyo Funamoto, BS

Mikiko Hayashi, BA

Kazunori Kodama, MD, PhD

Fumiyoshi Kasagi, PhD

Departments of Statistics (J.C. and S.F.), Epidemiology (M.H.),

Chief Scientist (K.K.), and the Institute of Radiation Epidemiology (F.K.), Radiation Effects Research Foundation, 5-2 Hijiyama Park, Minami-ku, Hiroshima-city, Hiroshima 732-0815, Japan

Edward F. Miles, MD

Department of Radiation Oncology, Box 3085,

Duke University Medical Center, Durham, NC 27710

Akihiko Suyama, $\mathrm{MD}, \mathrm{PhD}$

Midori Soda, MD

Department of Epidemiology, Radiation Effects Research Foundation, 8-6 Nakagawa 1-chrome, Nagasaki-city, Nagasaki 850, Japan 
The Journal of Bone \& Joint Surgery - Jbjs. org Volume 95-A • Number 3 · February 6, 2013
Ionizing Radiation Exposure and the Development of Soft-Tissue Sarcomas in Atomic-Bomb Survivors

\section{References}

1. Berwick M. Soft tissue sarcoma. In: Schottenfeld D, Fraumeni JF, editors. Cancer epidemiology and prevention. 3rd ed. Oxford: Oxford University Press; 2006. p 959-74.

2. Gutierrez JC, Perez EA, Franceschi D, Moffat FL Jr, Livingstone AS, Koniaris LG. Outcomes for soft-tissue sarcoma in 8249 cases from a large state cancer registry. J Surg Res. 2007 Jul;141(1):105-14. Epub 2007 May 18.

3. Mankin HJ, Hornicek FJ. Diagnosis, classification, and management of soft tissue sarcomas. Cancer Control. 2005 Jan-Feb;12(1):5-21.

4. Howe HL, Wu X, Ries LA, Cokkinides V, Ahmed F, Jemal A, Miller B, Williams M, Ward E, Wingo PA, Ramirez A, Edwards BK. Annual report to the nation on the status of cancer, 1975-2003, featuring cancer among U.S. Hispanic/Latino populations. Cancer. 2006 Oct 15;107(8):1711-42.

5. Hardell L, Sandström A. Case-control study: soft-tissue sarcomas and exposure to phenoxyacetic acids or chlorophenols. Br J Cancer. 1979 Jun;39(6):711-7.

6. Kogevinas M, Becher H, Benn T, Bertazzi PA, Boffetta P, Bueno-de-Mesquita HB, Coggon D, Colin D, Flesch-Janys D, Fingerhut M, Green L, Kauppinen T, Littorin M, Lynge E, Mathews JD, Neuberger M, Pearce N, Saracci R. Cancer mortality in workers exposed to phenoxy herbicides, chlorophenols, and dioxins. An expanded and updated international cohort study. Am J Epidemiol. 1997 Jun 15;145(12):1061-75.

7. Engels EA, Biggar RJ, Hall HI, Cross H, Crutchfield A, Finch JL, Grigg R, Hylton T, Pawlish KS, McNeel TS, Goedert JJ. Cancer risk in people infected with human immunodeficiency virus in the United States. Int J Cancer. 2008 Jul 1;123(1): 187-94.

8. Bekkers RL, Massuger LF, Berg PP, Haelst UG, Bulten J. Uterine malignant leiomyoblastoma (epithelioid leiomyosarcoma) during pregnancy. Gynecol Oncol. 1999 Mar;72(3):433-6.

9. Tavani A, Soler M, La Vecchia C, Negri E, Gallus S, Franceschi S. Body weight and risk of soft-tissue sarcoma. Br J Cancer. 1999 Nov;81(5):890-2.

10. Li FP, Fraumeni JF Jr, Mulvihill JJ, Blattner WA, Dreyfus MG, Tucker MA, Miller RW. A cancer family syndrome in twenty-four kindreds. Cancer Res. 1988 Sep 15;48(18):5358-62.

11. Wong FL, Boice JD Jr, Abramson DH, Tarone RE, Kleinerman RA, Stovall M, Goldman MB, Seddon JM, Tarbell N, Fraumeni JF Jr, Li FP. Cancer incidence after retinoblastoma. Radiation dose and sarcoma risk. JAMA. 1997 Oct 15;278(15): 1262-7.

12. Brady MS, Gaynor JJ, Brennan MF. Radiation-associated sarcoma of bone and soft tissue. Arch Surg. 1992 Dec;127(12):1379-85.

13. Falk H, Telles NC, Ishak KG, Thomas LB, Popper H. Epidemiology of thorotrastinduced hepatic angiosarcoma in the United States. Environ Res. 1979 Feb; 18(1):65-73.

14. Huang J, Mackillop WJ. Increased risk of soft tissue sarcoma after radiotherapy in women with breast carcinoma. Cancer. 2001 Jul 1;92(1):172-80.

15. Karlsson $P$, Holmberg E, Samuelsson A, Johansson KA, Wallgren A. Soft tissue sarcoma after treatment for breast cancer-a Swedish population-based study. Eur J Cancer. 1998 Dec;34(13):2068-75.

16. Buatti JM, Harari PM, Leigh BR, Cassady JR. Radiation-induced angiosarcoma of the breast. Case report and review of the literature. Am J Clin Oncol. 1994 Oct:17(5):444-7.

17. Killion MJ, Brodovsky HS, Schwarting R. Pericardial angiosarcoma after mediastinal irradiation for seminoma. A case report and a review of the literature. Cancer. 1996 Aug 15;78(4):912-7.

18. Mark RJ, Poen JC, Tran LM, Fu YS, Juillard GF. Angiosarcoma. A report of 67 patients and a review of the literature. Cancer. 1996 Jun 1;77(11):2400-6.

19. Davidson T, Westbury G, Harmer CL. Radiation-induced soft-tissue sarcoma. $\mathrm{Br}$ J Surg. 1986 Apr;73(4):308-9.

20. Rustemeyer $P$, Micke $O$, Blasius $S$, Peters $P E$. Radiation-induced malignant mesenchymoma of the chest wall following treatment for breast cancer. Br J Radiol. 1997 Apr;70(832):424-6.

21. Amendola BE, Amendola MA, McClatchey KD, Miller CH Jr. Radiation-associated sarcoma: a review of 23 patients with postradiation sarcoma over a 50-year period. Am J Clin Oncol. 1989 Oct;12(5):411-5.

22. Barnes M, Duray P, DeLuca A, Anderson W, Sindelar W, Kinsella T. Tumor induction following intraoperative radiotherapy: late results of the National Cancer Institute canine trials. Int J Radiat Oncol Biol Phys. 1990 Sep;19(3):651-60. 23. Rubino $C$, Shamsaldin A, Lê MG, Labbé M, Guinebretière JM, Chavaudra J, de Vathaire $F$. Radiation dose and risk of soft tissue and bone sarcoma after breast cancer treatment. Breast Cancer Res Treat. 2005 Feb;89(3):277-88.

24. Virtanen A, Pukkala $E$, Auvinen $A$. Incidence of bone and soft tissue sarcoma after radiotherapy: a cohort study of 295,712 Finnish cancer patients. Int J Cancer. 2006 Feb 15;118(4):1017-21.

25. Kim JH, Chu FC, Woodard HQ, Melamed MR, Huvos A, Cantin J. Radiationinduced soft-tissue and bone sarcoma. Radiology. 1978 Nov;129(2):501-8. 26. Wei Z, Xie Y, Xu J, Luo Y, Chen F, Yang Y, Huang Q, Tang A, Huang G. Radiationinduced sarcoma of head and neck: 50 years of experience at a single institution in an endemic area of nasopharyngeal carcinoma in China. Med Oncol. 2012 Jun;29(2):670-6. Epub 2011 Jan 23.

27. van Geel AN, Wouters MW, Lans TE, Schmitz PI, Verhoef C. Chest wall resection for adult soft tissue sarcomas and chondrosarcomas: analysis of prognostic factors. World J Surg. 2011 Jan;35(1):63-9.

28. Schwarz RE, Burt M. Radiation-associated malignant tumors of the chest wall. Ann Surg Oncol. 1996 Jul;3(4):387-92.

29. Samartzis D, Nishi N, Hayashi M, Cologne J, Cullings HM, Kodama K, Miles $\mathrm{EF}$, Funamoto S, Suyama A, Soda M, Kasagi F. Exposure to ionizing radiation and development of bone sarcoma: new insights based on atomic-bomb survivors of Hiroshima and Nagasaki. J Bone Joint Surg Am. 2011 Jun 1;93(11): 1008-15.

30. Korley FK, Pham JC, Kirsch TD. Use of advanced radiology during visits to US emergency departments for injury-related conditions, 1998-2007. JAMA. 2010 Oct 6;304(13):1465-71. Erratum in: JAMA. 2010 Nov 3;304(17):1901.

31. Biswas D, Bible JE, Bohan M, Simpson AK, Whang PG, Grauer JN. Radiation exposure from musculoskeletal computerized tomographic scans. J Bone Joint Surg Am. 2009 Aug;91(8):1882-9.

32. Mariscalco MW, Yamashita T, Steinmetz MP, Krishnaney AA, Lieberman IH, Mroz TE. Radiation exposure to the surgeon during open lumbar microdiscectomy and minimally invasive microdiscectomy: a prospective, controlled trial. Spine (Phila Pa 1976). 2011 Feb 1;36(3):255-60.

33. Muirhead CR, O'Hagan JA, Haylock RG, Phillipson MA, Willcock T, Berridge GL, Zhang W. Mortality and cancer incidence following occupational radiation exposure: third analysis of the National Registry for Radiation Workers. Br J Cancer. 2009 Jan 13;100(1):206-12.

34. Rampersaud YR, Foley KT, Shen AC, Williams S, Solomito M. Radiation exposure to the spine surgeon during fluoroscopically assisted pedicle screw insertion. Spine (Phila Pa 1976). 2000 Oct 15;25(20):2637-45.

35. Shilnikova NS, Preston DL, Ron E, Gilbert ES, Vassilenko EK, Romanov SA, Kuznetsova IS, Sokolnikov ME, Okatenko PV, Kreslov VV, Koshurnikova NA. Cancer mortality risk among workers at the Mayak nuclear complex. Radiat Res. 2003 Jun;159(6):787-98.

36. Cologne JB, Preston DL. Longevity of atomic-bomb survivors. Lancet. $2000 \mathrm{Jul}$ 22;356(9226):303-7.

37. Hollingsworth JW. Delayed radiation effects in survivors of the atomic bombings. A summary of the findings of the Atomic Bomb Casualty Commission, 19471959. N Engl J Med. 1960 Sep 8;263:481-7.

38. Mabuchi K, Soda M, Ron E, Tokunaga M, Ochikubo S, Sugimoto S, Ikeda T, Terasaki M, Preston DL, Thompson DE. Cancer incidence in atomic bomb survivors. Part I: Use of the tumor registries in Hiroshima and Nagasaki for incidence studies. Radiat Res. 1994 Feb;137(2 Suppl):S1-16.

39. Preston DL, Ron E, Tokuoka S, Funamoto S, Nishi N, Soda M, Mabuchi K, Kodama K. Solid cancer incidence in atomic bomb survivors: 1958-1998. Radiat Res. 2007 Jul;168(1):1-64.

40. Shimizu Y, Kodama K, Nishi N, Kasagi F, Suyama A, Soda M, Grant EJ, Sugiyama H. Sakata R, Moriwaki H, Hayashi M, Konda M, Shore RE. Radiation exposure and circulatory disease risk: Hiroshima and Nagasaki atomic bomb survivor data, 1950-2003. BMJ. 2010 Jan 14:340:b5349. doi: 10.1136/bmj.b5349.

41. Shimizu $Y$, Schull WJ, Kato $H$. Cancer risk among atomic bomb survivors. The RERF Life Span Study. Radiation Effects Research Foundation. JAMA. 1990 Aug 1:264(5):601-4.

42. Thompson DE, Mabuchi K, Ron E, Soda M, Tokunaga M, Ochikubo S, Sugimoto $\mathrm{S}$, Ikeda T, Terasaki M, Izumi S, et al. Cancer incidence in atomic bomb survivors. Part II: Solid tumors, 1958-1987. Radiat Res. 1994 Feb;137(2 Suppl):S17-67.

Erratum in: Radiat Res 1994 Jul;139(1):129.

43. Preston DL, Pierce DA, Shimizu Y, Cullings HM, Fujita S, Funamoto S, Kodama $\mathrm{K}$. Effect of recent changes in atomic bomb survivor dosimetry on cancer mortality risk estimates. Radiat Res. 2004 Oct;162(4):377-89.

44. Ron E, Carter R, Jablon S, Mabuchi K. Agreement between death certificate and autopsy diagnoses among atomic bomb survivors. Epidemiology. 1994 Jan;5(1): 48-56.

45. Preston DL, Lubin JH, Pierce DA, McConney ME. EPICURE: user's guide. Seattle: HiroSoft International Corporation; 1993.

46. Cullings HM, Cologne JB. Risk from ionizing radiation. In: Melnick EL, Everitt BS, editors. Encyclopedia of quantitative risk analysis and assessment. London: John Wiley \& Sons; 2008. p 1540-6.

47. Walsh L. A short review of model selection techniques for radiation epidemiology. Radiat Environ Biophys. 2007 Aug;46(3):205-13. Epub 2007 Apr 28.

48. National Council on Radiation Protection and Measurements (NCRP). Report no. 093. Ionizing radiation exposure of the population of the United States. Washington, DC: NCRP; 1987.

49. National Research Council. Health risks from exposure to low levels of ionizing radiation: BEIR VII phase 2. Washington, DC: The National Academies Press; 2006. 
The Journal of Bone \& Joint Surgery $\cdot$ Jbjs.org VOLUme 95-A • Number $3 \cdot$ FEBRUARY 6, 2013
Ionizing Radiation Exposure and the Development of Soft-Tissue Sarcomas in ATomic-Bomb Survivors
50. Samartzis $\mathrm{D}$, Cheung $\mathrm{KM}$. lonizing radiation exposure and the development of intervertebral disc degeneration in humans: myth or reality. Spine J. 2011 Oct;11(10):979-82. Epub 2011 Sep 1.

51. Baker JE, Moulder JE, Hopewell JW. Radiation as a risk factor for cardiovascular disease. Antioxid Redox Signal. 2011 Oct 1;15(7):1945-56. Epub 2011 Mar 23.

52. Ferrari $A$, Sultan I, Huang $T T$, Rodriguez-Galindo $C$, Shehadeh $A$, Meazza $C$, Ness KK, Casanova M, Spunt SL. Soft tissue sarcoma across the age spectrum: a populationbased study from the Surveillance Epidemiology and End Results database. Pediatr Blood Cancer. 2011 Dec 1;57(6):943-9. doi: 10.1002/pbc.23252. Epub 2011 Jul 25.

53. Pirzkall A, Carol M, Lohr F, Höss A, Wannenmacher M, Debus J. Comparison of intensity-modulated radiotherapy with conventional conformal radiotherapy for complex-shaped tumors. Int J Radiat Oncol Biol Phys. 2000 Dec 1;48(5):1371-80.

54. Pirzkall A, Carol MP, Pickett $B$, Xia P, Roach M 3rd, Verhey $L$. The effect of beam energy and number of fields on photon-based IMRT for deep-seated targets. Int J Radiat Oncol Biol Phys. 2002 Jun 1;53(2):434-42.

55. Thilmann C, Sroka-Perez G, Krempien R, Hoess A, Wannenmacher M, Debus J. Inversely planned intensity modulated radiotherapy of the breast including the internal mammary chain: a plan comparison study. Technol Cancer Res Treat. 2004 Feb;3(1):69-75.
56. Williams PO, Hounsell AR. X-ray leakage considerations for IMRT. Br J Radiol. 2001 Jan; 74(877):98-100.

57. Zelefsky MJ, Chan H, Hunt M, Yamada Y, Shippy AM, Amols H. Long-term outcome of high dose intensity modulated radiation therapy for patients with clinically localized prostate cancer. J Urol. 2006 Oct;176(4 Pt 1):1415-9.

58. Portelance L, Chao KS, Grigsby PW, Bennet H, Low D. Intensity-modulated radiation therapy (IMRT) reduces small bowel, rectum, and bladder doses in patients with cervical cancer receiving pelvic and para-aortic irradiation. Int J Radiat Oncol Biol Phys. 2001 Sep 1;51(1):261-6.

59. Wang JX, Inskip PD, Boice JD Jr, Li BX, Zhang JY, Fraumeni JF Jr. Cancer incidence among medical diagnostic X-ray workers in China, 1950 to 1985. Int J Cancer. 1990 May 15;45(5):889-95.

60. Howell RM, Ferenci MS, Hertel NE, Fullerton GD, Fox T, Davis LW. Measurements of secondary neutron dose from $15 \mathrm{MV}$ and $18 \mathrm{MV}$ IMRT. Radiat Prot Dosimetry. 2005;115(1-4):508-12.

61. Howell RM, Hertel NE, Wang Z, Hutchinson J, Fullerton GD. Calculation of effective dose from measurements of secondary neutron spectra and scattered photon dose from dynamic MLC IMRT for $6 \mathrm{MV}, 15 \mathrm{MV}$, and $18 \mathrm{MV}$ beam energies. Med Phys. 2006 Feb;33(2):360-8. 